DOI: http://dx.doi.org/10.21276/ap.2019.8.2.6

Original article

\title{
Effect of green tea extract on the carbofuran induced toxicity in wistar rats
}

\author{
Binitha P. Purushothaman and Ramadasan Kuttan** \\ Royal Dental College, Chalissery, Palakkad-679536, Kerala, India \\ *Amala Cancer Research Centre, Amala Nagar, Thrissur-680555, Kerala, India
}

Received July 20, 2019: Revised August 30, 2019: Accepted September 5, 2019: Published online December 30, 2019

\begin{abstract}
The present study is aimed to assess the effect of an extract of green tea on carbofuran induced toxicity in Wistar rats. Wistar rats were treated with carbofuran $(5 \mathrm{mg} / \mathrm{kg}$ b.wt orally) for 30 days in the presence and absence of different concentrations of green tea extract. Administration of green tea extract was found to significantly reduce carbofuran induced toxicity in Wistar rats. Administration of green tea extract restored acetylcholinesterase (AChE) as well as other serum and tissue marker enzymes such as, lactate dehydrogenase (LDH), creatine kinase (CK) and gamma glutamyl transferase $(\gamma-\mathrm{GT})$, mitochondrial and carbohydrate metabolizing enzymes, which were altered by carbofuran. Decreased levels of antioxidant enzymes and GSH during carbofuran administration were increased by the green tea administration. Similarly, green tea extract administration reduced oxidative stress markers which were increased during carbofuran administration. Moreover, altered neurobehavioral problems produced by carbofuran were reversed by the green tea administration. Biochemical alterations were accompanied by histopathological changes resulted from carbofuran toxicity which were ameliorated following green tea administration. These studies concluded that green tea administration effectively protected the rats from carbofuran toxicity.
\end{abstract}

Key words: Carbofuran, green tea, acetylcholinesterase, oxidative stress, mitochondrial enzymes, carbohydrate metabolizing enzymes

\section{Introduction}

The rivalry between the pests and human has been there ever since beginning of civilized mankind. Though, the pest suppression with synthetic chemicals is the quickest and surest method of pest management, however, persistence of pesticides in the food chain and the development of resistance in the pests towards pesticides, are the two serious problems encountered. The toxicity of pesticides and their degradation products is making these chemical substances a potential hazard by contaminating our environment (Salman et al., 2011). Carbofuran (2,3-dihydro-2, 2-dimethyl- 7- benzofuranyl methyl carbamate) is a broad spectrum, non-cumulative carbamate insecticide which is marketed under the trade names such as, FuradanR, CuraterrR, Bay 70143, FMC 10242, ENT-27,164 and Niagara $10242 R$. It is applied in granular form or aerially, on a variety of crops such as corn, grapes, banana and wheat in different parts of the world. Carbofuran is also used to control soil dwelling and foliar-feeding insects and vectors such as corn rootworm, mosquitoes, weevil, and aphids (Tottor, 1991). Primary mechanism of toxicity of carbofuran is the inhibition of serine group of acetylcholinesterase via carbamoylation at the nerve terminals (Fukuto, 1990). Carbofuran's cholinesterase inhibiting effect is short

Author for correspondence: Dr. Ramadasan Kuttan Professor, Amala Cancer Research Centre, Amala Nagar, Thrissur-680555, Kerala, India

E-mail: amalacancerresearch@gmail.com

Tel.: +91-9447123071

Copyright (C) 2019 Ukaaz Publications. All rights reserved.

Email: ukaaz@yahoo.com; Website: www.ukaazpublications.com term and reversible. Despite being banned in several countries, it is still used in some countries to replace other toxic organophosphate pesticides. Hence, the presence of carbofuran residues was reported in the ground, surface water, air, food and wildlife, thus causing serious toxic effects to the non-target organism including human (Farahani et al., 2007). Extracts of the tea plant (Camellia sinensis) belongs to the family Theacaceae are widely used as dietary supplements (Bun et al., 2006). Green tea has attracted significant attention, both in the scientific and in consumer communities for its health benefits for a variety of disorders, ranging from cancer to weight loss (Chandra and Choundry, 2011). It is widely consumed throughout the world and is also known to possess beneficial properties including antipyretic, diuretic, anti-oxidative, and antihepatotoxic activities (Paschkaet al., 1998, Ahmad and Mukhtar, 1999, Hsu et al., 2001, Srinivasan et al., 2006).

Green tea contains flavonoids, mainly catechins (flavan-3-ols) that form nearly $30-40 \%$ of the dry weight of green tea (Polu et al., 2015) (Balentine et al., 1997) which include epigallocatechin-3gallate (EGCG) (89\%), epigallocatechin (EGC); (19\%), epicatechin3-gallate (ECG) (13.6\%), epicatechin (EC) (6.4\%), and gallic acid (GA). In addition to these, caffeic acid, kaempferol, myricetin and quercetin, volatile oils as well as vitamins like B,C, E and folic acid xanthine bases (caffeine and theophylline); minerals and trace elements ( $\mathrm{Ca}, \mathrm{Mg}, \mathrm{Cr}, \mathrm{Mn}, \mathrm{Fe}, \mathrm{Cu}, \mathrm{Zn}$ and $\mathrm{Se}$ ), tannins and amino acids (major one is threonine) are also present (Zhang et al., 2006). The increasing interest in the health properties of tea extract and its main catechin polyphenols have led to a significant rise in scientific 
investigation for prevention and therapy against several diseases (Mandel et al., 2006).

Carbofuran has been shown to induce oxidative stress by reducing levels of antioxidant enzymes (Binitha et al., 2015). The present study is focused on the effect of the green tea extract to reduce carbofuran induced neurotoxicity and tissue toxicity in Wistar rats. We have further investigated the effect of the green tea extract on the restoration of mitochondrial enzymes, carbohydrate metabolizing enzymes, antioxidant enzymes as well as oxidative stress induced by carbofuran.

\section{Materials and Methods}

\subsection{Chemicals and reagents}

The green tea extract was supplied by Synthite Industries Ltd, Kerala state, India. Carbofuran was purchased from Sigma Aldrich, USA. 2,6-Dichlorophenol indophenol sodium salt (DCPIP), trisodiumisocitrate, $\alpha$-ketoglutarate, bovine serum albumin (BSA), oxaloacetate, phenazinemethosulfate and fructose 1,6 bis phosphate were purchased from Sigma-Aldrich, St. Louis, MO. Nitrobluetetrazolium (NBT), glutathione (GSH) and 5, 52 dithiobis (2-niotrobenzoic acid) (DTNB) were supplied by Sisco Research Laboratories Pvt. Ltd (Mumbai, India). Thiobarbituric acid was obtained from Himedia Laboratories (Mumbai, India).

Acetylcholinesterase, creatine kinase, gamma glutamyl transferase and lactate dehydrogenase assays were carried, using biochemical kits, supplied by Agappe Diagnostics Ltd (Kerala, India), Euro Industrial Chemicals Ltd (India), and Linear Chemicals (Spain), Merck specialities (Mumbai, India), respectively. Nicotinamide adenine dinucleotide $\left(\mathrm{NAD}^{+}\right)$sodium salt, nicotinamide adenine dinucleotide (reduced) (NADH) and adeninine -5- triphosphate disodium salt (ATP-Na) were purchased from Sisco Research Laboratories Pvt Ltd, Mumbai, India. All the other reagents and chemicals used were of analytical reagent grade.

\subsection{Animals}

Male Wistar rats (110-125 gm) were purchased from the Small Animal Breeding Station, Mannuthy, and Kerala, India and were housed in well ventilated cages under controlled conditions of light and humidity and provided with normal rat feed (Krish Scientists Shopee, Bangalore, India) and water ad libitum. All the animal experiments were done according to the instructions of Committee for the Purpose of Control and Supervision of Experiments on Animals (Sanction No.149/PO/Rc/S/1999/CPCSEA) and implemented through Institutional Animal Ethics Committee of Amala Cancer Research Centre.

Rats were randomly divided into 5 groups, each containing 6 animals/ group. Rats in Group I served as a normal vehicle control and was given peanut oil $(0.5 \mathrm{ml} / \mathrm{rat})$. Rats in Group II, control were given carbofuran in peanut oil at a dose of $5 \mathrm{mg} / \mathrm{kg}$ b.wt for 30 days. Rats in Groups III, IV and V were given the same dose of carbofuran along with different doses of green tea, 500,250 and $100 \mathrm{mg} / \mathrm{kg}$ b.wt, respectively dissolved in warm water. The animals were treated with respective drug doses through oral gavage for 30 days. 10 days before sacrifice, carbofuran induced behavioral problems, were tested by grip strength test, rotarod test and pain threshold test.

\subsection{Grip strength test}

The animals treated with carbofuran in the presence and absence of green tea extract were exposed to a horizontal griddle and made grasp the griddle with forelimbs and hindlimbs. The point at which both forelimbs and hindlimbs grasp were broken was considered as the time when the animal is fatigued. The time taken until the grasp of both hind and forelimbs were broken was considered as the endurance capacity of the animal. The procedure was repeated for 5 consecutive days and average endurance capacity in seconds was taken.

\subsection{Pain threshold test}

Arteryclip was applied to the root of tail of rat treated with carbofuran with and without green tea extract to induce pain. The animal quickly responded by biting the tail near the location of the clip. The time between stimulation of onset and response was measured by as top watch. The procedure was repeated for 5 consecutive days and average pain threshold in seconds was taken for each animal.

\subsection{Rotarod test}

Skeletal muscle relaxation induced by a test compound was evaluated by testing the ability of rats to remain on the rotating rotarod treadmill. The time was measured from the start of acceleration period until the rat fell off the drum. The procedure was repeated for 5 consecutive days and average performance time in seconds was taken (Vogel, 2002).

\subsection{Analysis of marker enzymes}

At the end of the experiment, animals of each group were sacrificed. Blood samples were collected and was allowed to clot and then centrifuged at $2000 \mathrm{rpm}$ for $10 \mathrm{~min}$. Brain, liver, intestine and kidney were excised and washed with ice cold saline for the analysis of tissue enzymes. For this, brain, intestine and kidney homogenates $(10 \%, \mathrm{~W} / \mathrm{V})$ and liver $(25 \% \mathrm{~W} / \mathrm{V})$ were prepared in Tris-HCl buffer $(0.1 \mathrm{M}, \mathrm{pH} 7)$. Serum and tissue marker enzymes such as acetylcholinesterase (AchE), creatine kinase (CK), lactate dehydrogenase (LDH) and gamma glutamyl transferase $(\gamma-\mathrm{GT})$ were analysed using commercially available kits.

\subsection{Isolation of mitochondria}

Immediately after sacrifice, liver was used for analysis of mitochondrial enzymes. Liver was homogenized in $0.25 \mathrm{M}$ sucrose containing $1 \mathrm{mM}$ EDTA and the suspension was centrifuged initially at $1000 \mathrm{~g}$ for $10 \mathrm{~min}$. The supernatants were pooled and centrifuged for $10 \mathrm{~min}$ at $10000 \mathrm{~g}$ in a refrigerated centrifuge. The pellet collected represented mitochondrial fraction. Mitochondrial pellet was suspended in $2 \mathrm{ml}$ of $0.25 \mathrm{M}$ sucrose and used as the enzyme source and stored in ice until required (Susin et al., 2000).

\subsection{Analysis of mitochondrial enzymes}

Isocitrate dehydrogenase (ICDH) activity was estimated according to the method of Fatania et al. (1993). The rate of reduction of $\mathrm{NAD}^{+}$in the presence of trisodiumisocitrate was measured at 340 $\mathrm{nm}$ and expressed as $\mu$ moles of $\mathrm{NAD}^{+}$reduced $/$minute $/ \mathrm{mg}$ protein using the extinction coefficient of NADH $\left(6.3 \mathrm{mM}^{-1}\right)$. Succinate dehydrogenase (SDH) activity was estimated by the method of Nulton-Persson and Szweda (2001) and the activity was estimated 
from the rate of reduction of dichloro phenol indophenol (DCPIP) in the presence of sodium succinate at $600 \mathrm{~nm}$. Malate dehydrogenase (MDH) activity was estimated by the method of Mehler et al. (1948), following the rate of oxidation of NADH in the presence of oxaloacetate at $340 \mathrm{~nm}$. The activity of NADH - dehydrogenase is expressed as $\mathrm{n}$ moles of NADH oxidized per minute per $\mathrm{mg}$ of protein (Minakami et al., 1962).

\subsection{Analysis of carbohydrate metabolizing enzymes}

Liver homogenate was used for the analysis of carbohydrate metabolizing enzymes. Hexokinase was assayed according to the method of Brandstrup et al. (1957). In the presence of phenazinemethosulfate (PMS), NADPH reduces the blue dye, dichlorophenol indophenol, to the colour-less form. The rate at which colour visually disappears in the reaction mixture is proportional to the glucose-6-phosphate dehydrogenase content of the sample (Eels and Kirkman, 1961). The enzyme activity is expressed as $\mathrm{n}$ moles of glucose-6-phosphate liberated $/ \mathrm{min} / \mathrm{mg}$ protein. Fructose -1, 6-diphosphatase was assayed by the method of Gancedo and Gancedo (1971) and was expressed as n moles of $\mathrm{Pi}$ liberated $/ \mathrm{min} / \mathrm{mg}$ protein. Inorganic phosphorous estimation is based on the formation of phosphomolybdic acid by the reaction between phosphate and molybdic acid and its subsequent reduction to a dark blue phosphomolybdic acid, the intensity of which is proportional to the phosphate ion concentration (Fiske and Subbarow, 1925). The values were expressed as $\mu \mathrm{g}$ per $\mathrm{mg}$ protein. Glucose-6-phosphatase was assayed according to the method of King (King, 1965) and is expressed as $\mu$ moles of Pi liberated $/ \mathrm{min} /$ mg protein.

\subsection{Antioxidant enzymes and glutathione}

Liver homogenate $(25 \% \mathrm{~W} / \mathrm{V}$ in $0.1 \mathrm{M}$ Tris $\mathrm{HCL})$ was centrifuged at $10,000 \mathrm{rpm}$ for thirty minutes at $4^{\circ} \mathrm{C}$ and was used for antioxidant enzyme analysis. Superoxide dismutase activity was measured by the NBT reduction method (Mc cord and Fridovich, 1969). Glutathione (GSH) levels were assayed based on the reaction with DTNB (Moron and Depierre, 1979). The assay of glutathione peroxidase was performed based on the oxidation of GSH in the presence of hydrogen peroxide (Hafeman, 1974). Catalase (CAT) activity was estimated by measuring the rate of decomposition of hydrogen peroxide at $240 \mathrm{~nm}$ (Aebi, 1974).

\subsection{Determination of oxidative stress}

Liver homogenate $(25 \%)$ were prepared in $0.1 \mathrm{M}$ Tris $\mathrm{HCl}$. Lipid peroxidation in the liver homogenate was estimated by the thiobarbituric acid method (Ohkawa et al., 1979). Estimation of tissue hydroperoxides and conjugated dienes were done by the modified method of John and Steven (1978). Total protein in the tissues was estimated by Lowry's method (Lowry et al., 1951).

\subsection{Histopathology}

Histopathological analysis was done on tissues brain, liver, kidney, spleen, intestine and stomach tissues taken from normal, carbofuran treated animals as well as carbofuran and green tea $(500 \mathrm{mg} / \mathrm{kgb} . \mathrm{wt})$ treated animals.

\subsection{Statistical analysis}

The values are expressed as mean \pm SD. The statistical evaluation was done by comparing the data between normal and carbofuran treated as well as carbofuran and green tea extract treated groups by one-way analysis of variance (ANOVA), followed by appropriate (post hoc) Dunnet multiple comparison test using Graph pad Instat software (version 3.05).

\section{Results}

Effect of the green tea extract on carbofuran induced neuro behavioral changes.

\subsection{Pain threshold}

Carbofuran treated animals exhibited significant increase in pain threshold test as compared with normal rats $(p>0.01)$. Carbofuran with green tea extract significantly decreased the pain threshold as compared with carbofuran treated animals. Carbofuran with green tea $500 \mathrm{mg} / \mathrm{kg}$ b.wt was the most effective group $(p>0.01)$ when compared to other treated groups such as 250 and $100 \mathrm{mg} / \mathrm{kg} \mathrm{b} . \mathrm{wt}$ (Table 1) of green tea extract.

Table 1: Effect of green tea administration on carbofuran induced changes in neurobehavioural study

\begin{tabular}{|l|l|l|l|}
\hline Group & $\begin{array}{l}\text { Pain threshold } \\
\text { (In seconds) }\end{array}$ & $\begin{array}{l}\text { Grip strength method } \\
\text { (In seconds) }\end{array}$ & $\begin{array}{l}\text { Rotarod } \\
\text { (In seconds) }\end{array}$ \\
\hline Normal $^{1}$ & $01.01 \pm 1.43$ & $40.65 \pm 1.70$ & $31.45 \pm 0.43$ \\
$\mathrm{Carb}^{1} 5 \mathrm{mg} / \mathrm{kg}$ & $20.12 \pm 0.56^{* *}$ & $03.11 \pm 4.87^{* *}$ & $13.17 \pm 2.34 * *$ \\
$\mathrm{Carb}^{1}+\mathrm{GT}^{2} 500 \mathrm{mg} / \mathrm{kg}$ & $09.13 \pm 2.40^{* *}$ & $30.21 \pm 5.12 * *$ & $22.04 \pm 1.89 * *$ \\
$\mathrm{Carb}^{1}+\mathrm{GT}^{2} 250 \mathrm{mg} / \mathrm{kg}$ & $05.11 \pm 0.88^{* *}$ & $24.82 \pm 3.11^{* *}$ & $22.11 \pm 3.56^{* *}$ \\
$\mathrm{Carb}^{1}+\mathrm{GT}^{2} 200 \mathrm{mg} / \mathrm{kg}$ & $05.01 \pm 0.98^{* *}$ & $20.11 \pm 0.23^{* *}$ & $20.07 \pm 0.21 * *$ \\
\hline
\end{tabular}

Values are mean $\pm \mathrm{SD}(n=6) * * p<0.01$, significance was calculated against the normal and carbofuran treatment group as well as carbofuran and green tea treated groups. Treatment was continued for 30 days. ${ }^{1}$ Carbofuran. ${ }^{2}$ Green tea.

\subsection{Rotarod test}

Carbofuran treated rats showed significant decrease in rotarod test when compared with normal rats $(p<0.01)$. Green tea administration significantly elevated rotarod performance when compared to carbofuran alone treated animals $(p<0.01)$ (Table 1).

\subsection{Grip strength test}

When compared with normal animals, there was significant reduction of endurance capacity in grip strength test in carbofuran treated animals. Administration of carbofuran along with green tea produced significant elevation of endurance capacity in grip strength test when compared to carbofuran treated animals $(p<0.01)($ Table 1$)$. 
3.4 Effect of green tea extract on serum and tissue marker enzymes

The carbofuran administration showed lowered levels of serum and tissue AchE when compared to normal animals. Green tea treatment significantly elevated the AchE in carbofuran treated groups both in serum as well as in tissues when compared to carbofuran alone treated group $(p<0.01)$ (Table 2).

The level of CK (Table 3 ) was found to be increased in serum and all the tissues by treatment with carbofuran $(p<0.01)$. Increased levels of enzyme were found to be reduced by treatment with the green tea extract $(p<0.01)$.

LDH was found to be increased in serum, brain and liver $(p<0.01)$. Increased levels of LDH in these tissues were decreased by treatment with green tea $(p<0.01)$.

Levels of $\gamma$-GT were found to be increased in serum and liver $(p<0.01)$ after treatment with carbofuran. Increased $\gamma$-GT was found to be decreased by treatment with green tea extract administration $(p<0.01)$.

Table 2: Effect of green tea oncarbofuran induced changes in acetylcholinesterase activity in serum and various tissues

\begin{tabular}{|c|c|c|c|c|c|}
\hline \multirow[b]{2}{*}{ Group } & \multicolumn{5}{|c|}{ Acetylcholinesterase Activity } \\
\hline & Serum & Brain & Liver & Intestine & Kidney \\
\hline Normal & $5380.08 \pm 2.14$ & $2264.67 \pm 1.65$ & $2271.67 \pm 2.11$ & $2944.33 \pm 7.11$ & $2741.30 \pm 2.11$ \\
\hline Carbofuran $5 \mathrm{mg} / \mathrm{kg}$ & $1723.96 \pm 3.22 * *$ & $1434.33 \pm 0.65 * *$ & $1392.00 \pm 3.01 * *$ & $1283.33 \pm 3.45^{* *}$ & $2565.65 \pm 0.13^{* *}$ \\
\hline $\begin{array}{l}\text { Carbofuran } 5 \mathrm{mg} / \mathrm{kg}+ \\
\text { Green tea } 500 \mathrm{mg} / \mathrm{kg} \text { b.wt }\end{array}$ & $4587.23 \pm 4.23^{* *}$ & $2491.33 \pm 0.11 * *$ & $2859.7 \pm 5.90 * *$ & $2566.67 \pm 2.11 * *$ & $2942.78 \pm 1.34 * *$ \\
\hline $\begin{array}{l}\text { Carbofuran } 5 \mathrm{mg} / \mathrm{kg}+\text { Green } \\
\text { tea } 250 \mathrm{mg} / \mathrm{kg} \text { b.wt }\end{array}$ & $3510.11 \pm 0.56^{* *}$ & $2364.67 \pm 3.22 * *$ & $2674.31 \pm 2.11^{* *}$ & $1811.67 \pm 5.67^{* *}$ & $3397.33 \pm 5.98 * *$ \\
\hline $\begin{array}{l}\text { Carbofuran } 5 \mathrm{mg} / \mathrm{kg}+\mathrm{Green} \\
\text { tea } 100 \mathrm{mg} / \mathrm{kg} \mathrm{b.wt}\end{array}$ & $3020.11 \pm 0.44 * *$ & $2261.27 \pm 2.11^{* *}$ & $2491.32 \pm 2.32 * *$ & $2376.01 \pm 2.45^{* *}$ & $2114.01 \pm 5.66^{* *}$ \\
\hline
\end{tabular}

Values are mean $\pm \mathrm{SD}(n=6) .{ }^{* *} p<0.01$, significance was calculated against the carbofuran group, green tea and carbofuran treatment were continued for 30 days. Unit for acetylcholinesterase activity (U/mg protein) in tissues and serum it is $\mathrm{U} / \mathrm{L}$.

Table 3: Effect of green tea on carbofuran induced changes in creatinekinase activity in serum and various tissues

\begin{tabular}{|c|c|c|c|c|c|}
\hline \multirow[b]{2}{*}{ Group } & \multicolumn{5}{|c|}{ Creatinekinase activity } \\
\hline & Serum & Brain & Liver & Kidney & Intestine \\
\hline Normal & $90.80 \pm 5.61$ & $112.00 \pm 1.92$ & $79.33 \pm 0.89$ & $145.00 \pm 5.23$ & $64.00 \pm 0.21$ \\
\hline Carbofuran $5 \mathrm{mg} / \mathrm{kg}$ b. wt & $124.67 \pm 0.12^{* *}$ & $197.67 \pm 0.11 * *$ & $201.67 \pm 7.22 * *$ & $224.67 \pm 4.11^{* *}$ & $234.00 \pm 7.11^{* *}$ \\
\hline $\begin{array}{l}\text { Carbofuran } 5 \mathrm{mg} / \mathrm{kg} \mathrm{b} \text {. wt }{ }^{+} \\
\text {green tea } 500 \mathrm{mg} / \mathrm{kg} \mathrm{b} . w t\end{array}$ & $101.33 \pm 1.97^{* *}$ & $66.67 \pm 3.67^{* *}$ & $93.00 \pm 1.12 * *$ & $110.33 \pm 0.32 * *$ & $078.01 \pm 5.3^{* *}$ \\
\hline $\begin{array}{l}\text { Carbofuran } 5 \mathrm{mg} / \mathrm{kg} \mathrm{b} \text {. wt }+ \\
\text { green tea } 250 \mathrm{mg} / \mathrm{kg} \text { b.wt }\end{array}$ & $69.67 \pm 7.12^{* *}$ & $104.00 \pm 2.86^{* *}$ & $145.00 \pm 7.3^{* *}$ & $72.64 \pm 1.45^{* *}$ & $80.93 \pm 3.43 * *$ \\
\hline $\begin{array}{l}\text { Carbofuran } 5 \mathrm{mg} / \mathrm{kg} \mathrm{b} \text {. wt }+ \\
\text { green tea } 100 \mathrm{mg} / \mathrm{kg} \text { b.wt }\end{array}$ & $89.00 \pm 2.12 * *$ & $80.67 \pm 4.11^{* *}$ & $82.43 \pm 3.6^{* *}$ & $124.23 \pm 1.67 * *$ & $52.09 \pm 6.45^{* *}$ \\
\hline
\end{tabular}

Values are mean $\pm \mathrm{SD}(n=6) .{ }^{* *} p<0.01$, significance was calculated against the normal and carbofuran group as well as green tea and carbofuran treated groups. Unit for creatinekinaseactivity (U/mg protein) for tissues and for serum (U/L).

Table 4: Effect of green tea oncarbofuran induced changes in lactate dehydrogenase activity in serum and various tissues

\begin{tabular}{|c|c|c|c|c|c|}
\hline \multirow[b]{2}{*}{ Group } & \multicolumn{5}{|c|}{ Lactate dehydrogenase activity } \\
\hline & Serum & Brain & Intestine & Kidney & Liver \\
\hline Normal & $95.23 \pm 0.1$ & $145.33 \pm 3.4$ & $188.33 \pm 2.9$ & $84.00 \pm 1.3$ & $160.33 \pm 9.7$ \\
\hline Carbofuran $5 \mathrm{mg} / \mathrm{kg}$ b.wt & $233.52 \pm 2.5^{* *}$ & $197.66 \pm 1.7^{* *}$ & $207.00 \pm 6.3^{\mathrm{ns}}$ & $104.33 \pm 1.2^{\mathrm{ns}}$ & $295.00 \pm 8.3^{* *}$ \\
\hline $\begin{array}{l}\text { Carbofuran } 5 \mathrm{mg} / \mathrm{kg} \mathrm{b} . \mathrm{wt}^{+} \\
\text {Green tea } 500 \mathrm{mg} / \mathrm{kg} \text { b.wt }\end{array}$ & $85.46 \pm 5.6^{* *}$ & $143.83 \pm 7.5^{* *}$ & $196.04 \pm 3.2^{\mathrm{ns}}$ & $76.00 \pm 0.8^{\mathrm{ns}}$ & $124.67 \pm 6.0^{* *}$ \\
\hline $\begin{array}{l}\text { Carbofuran } 5 \mathrm{mg} / \mathrm{kg} \text { b.wt }+ \\
\text { Green tea } 250 \mathrm{mg} / \mathrm{kg} \text { b.wt }\end{array}$ & $81.67 \pm 7.1^{* *}$ & $115.75 \pm 8.6^{* *}$ & $158.42 \pm 7.5^{\mathrm{ns}}$ & $100.05 \pm 0.7^{\mathrm{ns}}$ & $126.61 \pm 1.2^{* *}$ \\
\hline $\begin{array}{l}\text { Carbofuran } 5 \mathrm{mg} / \mathrm{kg} \mathrm{b} . w t+ \\
\text { Green tea } 100 \mathrm{mg} / \mathrm{kg} \text { b.wt }\end{array}$ & $119.33 \pm 6.2 * *$ & $166.16 \pm 6.2^{* *}$ & $194.00 \pm 5.3^{\mathrm{ns}}$ & $63.33 \pm 5.8^{\mathrm{ns}}$ & $96.61 \pm 1.4^{* *}$ \\
\hline
\end{tabular}

Values are mean $\pm \mathrm{SD}(n=6) .{ }^{* *} p<0.01, \mathrm{~ns}$; not significant, significance was calculated against the normal and carbofuran group as well as green tea and carbofuran treated groups. Unit for lactate dehydrogenase activity for tissues (U/mg protein) and serum it is U/L. 
Table 5: Effect of green tea on carbofuran induced changes in gamma glutamyltransferase ( $\gamma$-GT) activity in serum and various tissues gamma glutamyltransferase activity $(\gamma-\mathrm{GT})$

\begin{tabular}{|c|c|c|c|c|c|}
\hline \multirow[b]{2}{*}{ Group } & \multicolumn{5}{|c|}{ Gamma glutamyltransferase $(\gamma-G T)$ activity } \\
\hline & Serum & Brain & Liver & Kidney & Intestine \\
\hline Normal & $34.00 \pm 7.1$ & $120.11 \pm 5.6$ & $110.09 \pm 3.5$ & $88.01 \pm 2.5$ & $64.53 \pm 1.4$ \\
\hline Carbofuran $5 \mathrm{mg} / \mathrm{kg}$ b.wt & $165.4 \pm 2.6^{* *}$ & $110.83 \pm 8.9^{\text {ns }}$ & $291.07 \pm 3.6^{* *}$ & $80.01 \pm 2.9^{\mathrm{ns}}$ & $51.01 \pm 1.6^{\mathrm{ns}}$ \\
\hline $\begin{array}{l}\text { Carbofuran } 5 \mathrm{mg} / \mathrm{kg} \mathrm{b} . w \mathrm{t}+ \\
\text { Green tea } 500 \mathrm{mg} / \mathrm{kg}\end{array}$ & $44.00 \pm 5.7^{* *}$ & $168.33 \pm 6.3^{\mathrm{ns}}$ & $97.01 \pm 5.6^{* *}$ & $75.61 \pm 1.3^{\mathrm{ns}}$ & $69.08 \pm 0.3^{\mathrm{ns}}$ \\
\hline $\begin{array}{l}\text { Carbofuran } 5 \mathrm{mg} / \mathrm{kg} \text { b.wt+ } \\
\text { Green tea } 250 \mathrm{mg} / \mathrm{kg}\end{array}$ & $155.00 \pm 1.1 * *$ & $122.00 \pm 1.3^{\mathrm{ns}}$ & $188.05 \pm 3.5^{* *}$ & $72.01 \pm 1.1 \mathrm{~ns}$ & $99.01 \pm 5.8^{\mathrm{ns}}$ \\
\hline $\begin{array}{l}\text { Carbofuran } 5 \mathrm{mg} / \mathrm{kg} \text { b.wt+ } \\
\text { Green tea } 100 \mathrm{mg} / \mathrm{kg}\end{array}$ & $132.01 \pm 4.5^{* *}$ & $119.71 \pm 1.1^{\mathrm{ns}}$ & $180.11 \pm 1.5^{* *}$ & $70.58 \pm 9.3 \mathrm{~ns}$ & $82.01 \pm 1.5^{\mathrm{ns}}$ \\
\hline
\end{tabular}

Values are mean $\pm \mathrm{SD}(n=6) .{ }^{* *} p<0.01, \mathrm{~ns} ;$ not significant, significance was calculated against the normal and carbofuran group as well as green tea and carbofuran treated groups. Unit for tissues $\gamma$-GT (U/mg protein)and for serum was $(\mathrm{U} / \mathrm{L})$.

\subsection{Effect of green tea extract administration on mitochon- drial enzymes}

The levels of SDH, ICDH, MDH and NADH dehydrogenase were decreased in the control group animals treated with carbofuran alone when compared to the normal animals and the levels were significantly $(p<0.01)$ enhanced after green tea extract administration excepting in NADH dehydrogenase (not significant) (Table 6).

\subsection{Effect of green tea administration on carbohydrate metabolizing enzymes}

Hexokinase level was found to be significantly elevated in the liver of carbofurantreated animals and it was significantly reduced $(p<0.05)$ by green tea extract treatment. A significant reduction of glucose-6-phosphate dehydrogenase, glucose-6-phosphatase and fructose-1, 6-bis phosphatase levels were seen in carbofuran treated group $(p<0.01)$ and green tea extract administration restored these enzymes (Table 7) in a significant manner $(p<0.1)$.

\subsection{Effect of green tea on antioxidant enzymes and GSH levels}

The levels of SOD, CAT, GPX and GSH in the liver tissue were decreased in the carbofuran treated group of animals when compared to the normal animals and the levels were significantly $(p<0.01)$ enhanced by the green tea administration in a dose dependent manner (Table 8).

\subsection{Inhibition of carbofuran induced oxidative stress markers} by green tea

Markers of oxidative stress such as conjugated dienes, tissue hydroperoxides as well as lipid peroxide formation were high in the carbofuran alone treated animals $(p<01)$ compared with normal rats, and these parameters were significantly $(p<0.05)+(p<01)$ reduced to normal levels in green tea extract treated groups (Table 9).

Table 6: Effect of green tea on carbofuran induced changes in mitochondrial enzymes in liver

\begin{tabular}{|l|c|c|c|c|}
\hline \multicolumn{2}{|c|}{ Mitochondrial enzymes } \\
\hline Group & ICDH & MDH & SDH & NADH dehydrogenase \\
\hline Normal & $347.33 \pm 0.23$ & $248.50 \pm 4.67$ & $30.69 \pm 2.56$ & $33.33 \pm 3.23$ \\
Carbofuran $5 \mathrm{mg} / \mathrm{kg}$ & $244.00 \pm 1.89 * *$ & $100.38 \pm 9.09 * *$ & $08.17 \pm 3.65^{* *}$ & $14.33 \pm 2.34 * *$ \\
Carbofuran $5 \mathrm{mg} / \mathrm{kg}+$ Green tea $500 \mathrm{mg} / \mathrm{kg}$ & $327.67 \pm 5.23^{* *}$ & $227.04 \pm 1.33^{* *}$ & $32.12 \pm 4.32^{* *}$ & $12.05 \pm 3.11^{\mathrm{ns}}$ \\
Carbofuran $5 \mathrm{mg} / \mathrm{kg}+$ Green tea $250 \mathrm{mg} / \mathrm{kg}$ & $193.33 \pm 2.11^{*}$ & $126.36 \pm 2.13^{\mathrm{ns}}$ & $27.67 \pm 2.44^{* *}$ & $17.67 \pm 2.33^{\mathrm{ns}}$ \\
Carbofuran $5 \mathrm{mg} / \mathrm{kg}+$ Green tea $100 \mathrm{mg} / \mathrm{kg}$ & $188.67 \pm 5.98^{*}$ & $105.33 \pm 2.12^{\mathrm{ns}}$ & $17.05 \pm 2.43^{*}$ & $17.33 \pm 3.33 \mathrm{~ns}$ \\
\hline
\end{tabular}

Values are mean $\pm \mathrm{SD}(n=6)$. ** $p<0.01, * p<0.05$ significance was calculated against the normal and carbofuran group, carbofuranand green tea group. Carbofuran and green tea treatment were continued for 30 days. Enzymes analyzed were Isocitrate dehydrogenase (ICDH) ( $\mu$ moles of $\mathrm{NAD}^{+}$reduced/minute/mg protein); Malatae dehydrogenase (MDH) ( $\mu$ moles of NADH oxidized/min/mg protein); Succinate dehydrogenase $(\mathrm{SDH})$ (micromoles of DCPIP reduced/min/mg protein); NADH dehydrogenase (n moles of NADH oxidized per minute per mg of protein).ns; non significant

\subsection{Histopathological analysis}

Histopathological examination of carbofuran treated rat brain tissue indicated, showed foci of degeneration with stromal oedema (Figure 1). In animals treated with green tea, brain showed normal astrocytes and glial cells. Cerebellum appeared normal and there were nonecrotic foci. Carbofuran treated rat liver showed marked degenerative changes of hepatocytes, focal necrosis of hepatic tissue with collections of inflammatory cells and some are as showed haemorrhage. Green tea treatment reversed the changes.
Kidney sections of carbofuran treated rats demonstrated marked necrosis of tubular cells atrophy of the glomeruli, and areas of interstitial infiltration of round cells were found. Normal renal tubules and normal glomeruli were seen in green tea extract, treated groups. Mucosal hyperplasia, necrosis and squamous portion of stomach also showed inflammatory reaction in control stomach tissues. Green tea extract treatment groups showed normal mucosal glands and squamous glands. The examination of carbofuran treated intestine showed dense collections of lymphocytes, plasma cells, polymorphs and histiocytes. Intestinal tissues after green tea treatment had normal glands and villi lined bycolumnar cells. 
Table 7: Effect of green tea on carbofuran induced changes in carbohydrate metabolizing enzymes in liver

\begin{tabular}{|l|c|c|c|c|}
\hline \multirow{2}{*}{ Group } & \multicolumn{4}{|c|}{ Carbohydrate metabolizing enzymes } \\
\cline { 2 - 5 } & Hexokinase & Glucose-6-PO $\mathbf{4 H}$ & $\begin{array}{c}\text { Glucose-6- } \\
\text { phosphatase }\end{array}$ & $\begin{array}{c}\text { Fructose-1,6 bis } \\
\text { phosphatase }\end{array}$ \\
\hline Normal & $4.00 \pm 0.23$ & $2.21 \pm 4.23$ & $35.29 \pm 2.09$ & $67.08 \pm 2.12^{* *}$ \\
Carbofuran $5 \mathrm{mg} / \mathrm{kg}$ & $8.14 \pm 1.34 * *$ & $0.59 \pm 1.22^{* *}$ & $17.00 \pm 1.17^{* *}$ & $30.20 \pm 3.12^{* *}$ \\
Carbofuran $5 \mathrm{mg} / \mathrm{kg}+$ Green tea $500 \mathrm{mg} / \mathrm{kg}$ b.wt & $5.66 \pm 1.45^{*}$ & $2.13 \pm 3.12^{* *}$ & $31.83 \pm 5.87^{* *}$ & $71.20 \pm 2.43^{* *}$ \\
Carbofuran $5 \mathrm{mg} / \mathrm{kg}+$ Green tea $250 \mathrm{mg} / \mathrm{kg}$ b.wt & $3.50 \pm 4.98^{* *}$ & $0.83 \pm 0.12^{* *}$ & $34.44 \pm 6.12^{* *}$ & $79.56 \pm 1.32^{* *}$ \\
Carbofuran $5 \mathrm{mg} / \mathrm{kg}+$ Green tea $100 \mathrm{mg} / \mathrm{kg}$ b.wt & $5.20 \pm 6.32^{* *}$ & $0.91 \pm 3.09^{*}$ & $15.39 \pm 2.33^{* *}$ & $55.61 \pm 1.76^{*}$ \\
\hline
\end{tabular}

Values are expressed as mean $\pm \mathrm{SD} ; \mathrm{n}=6$. Statistical analysis was done by using one-way analysis of variance (ANOVA) followed by Dunnett's multiple comparison test. ${ }^{* *} p<0.01,{ }^{*} p<0.05$ significantly. Hexokinase; n moles of glucose-6-phosphate formed/min/mg protein, Glucose-6phosphate dehydrogenase (glucose-6- $\mathrm{PO}_{4} \mathrm{DH}$ ); units $/ \mathrm{mg}$ protein,Glucose-6-phosphatase; $\mu$ moles of Pi liberated $/ \mathrm{min} / \mathrm{mg}$ protein, Fructose1-6bisphosphatase; $\mathrm{n}$ moles of Pi liberated/min/mg protein, ns; non significant.

Table 8: Effect of green tea extract on carbofuran induced changes in antioxidant enzymes and GSH in liver

\begin{tabular}{|l|l|l|l|l|}
\hline \multirow{2}{*}{ Group } & \multicolumn{4}{|c|}{ Antioxidant enzymes } \\
\cline { 2 - 5 } & SOD & CAT & GPX & GS H \\
\hline Normal & $1.00 \pm 0.13$ & $5.45 \pm 2.11$ & $06.93 \pm 0.56$ & $09.93 \pm 4.12$ \\
Carbofuran $5 \mathrm{mg} / \mathrm{kg}$ b.wt & $0.57 \pm 4.12^{* *}$ & $0.97 \pm 1.09^{* *}$ & $02.85 \pm 6.76^{* *}$ & $06.40 \pm 1.23^{* *}$ \\
Carbofuran $5 \mathrm{mg} / \mathrm{kg}$ b.wt+Green tea $500 \mathrm{mg} / \mathrm{kg}$ b.wt & $0.96 \pm 1.71^{*}$ & $9.36 \pm 3.12^{*}$ & $10.72 \pm 0.1^{* *}$ & $10.61 \pm 1.1^{*}$ \\
Carbofuran $5 \mathrm{mg} / \mathrm{kg}$ b.wt+Green tea $250 \mathrm{mg} / \mathrm{kg}$ b.wt & $1.35 \pm 4.23^{* *}$ & $6.43 \pm 1.11^{* *}$ & $09.10 \pm 6.12^{* *}$ & $08.99 \pm 1.11^{\mathrm{ns}}$ \\
Carbofuran $5 \mathrm{mg} / \mathrm{kg}$ b.wt+Green tea $100 \mathrm{mg} / \mathrm{kg}$ b.wt & $0.86 \pm 1.12^{*}$ & $4.40 \pm 0.98^{\text {ns }}$ & $03.13 \pm 1.23^{\text {ns }}$ & $06.55 \pm 3.23^{\mathrm{ns}}$ \\
\hline
\end{tabular}

Catalase (CAT) unit- U/mg protein, Super oxide dismutase (SOD) unit- U/mg protein, Glutathoine peroxidase (GPx) unit- U/mg protein, Glutathione $(\mathrm{GSH})$ unit $\mathrm{n} \mathrm{mol} / \mathrm{ml}$.Values are mean $\pm \mathrm{SD}$ from 6 animals in each group. ${ }^{* *} p<0.01,{ }^{*} p<0.05$, significance was calculated against the normal and carbofuran group and carbofuran green tea group, green tea and carbofuran treatment were continued for 30 days.ns; nonsignificant.

Table 9: Effect of green tea on carbofuran induced changes in lipid peroxidation and oxidative stress markers in liver

\begin{tabular}{|l|l|c|c|}
\hline \multirow{2}{*}{ Group } & \multicolumn{3}{|c|}{ Oxidative stress } \\
\cline { 2 - 4 } & Lipid peroxidation & Conjugated diene & Hydroperoxides \\
\hline Normal & $2.57 \pm 1.98$ & $1.06 \pm 4.56$ & $6.25 \pm 1.23$ \\
Carbofuran $5 \mathrm{mg} / \mathrm{kg}$ b.wt & $5.20 \pm 0.99^{* *}$ & $1.9 \pm 5.12^{* *}$ & $12.39 \pm 4.54^{* *}$ \\
Carbofuran $5 \mathrm{mg} / \mathrm{kg}$ b.wt+green tea $500 \mathrm{mg} / \mathrm{kg}$ b.wt & $3.58 \pm 12.1^{* *}$ & $1.34 \pm 0.89^{*}$ & $6.77 \pm 3.11^{* *}$ \\
Carbofuran $5 \mathrm{mg} / \mathrm{kg}$ b.wt+green tea $250 \mathrm{mg} / \mathrm{kg}$ b.wt & $3.51 \pm 3.67^{*}$ & $01.65 \pm 0.56^{\mathrm{ns}}$ & $10.14 \pm 5.67^{*}$ \\
Carbofuran $5 \mathrm{mg} / \mathrm{kg}$ b.wt + green tea $100 \mathrm{mg} / \mathrm{kg}$ b.wt & $4.57 \pm 0.12^{\mathrm{ns}}$ & $01.92 \pm 5.67^{\mathrm{ns}}$ & $11.08 \pm 3.45^{\mathrm{ns}}$ \\
\hline
\end{tabular}

Values are mean $\pm \mathrm{SD}$ from 6 animals in each group, ${ }^{*} p<0.05, \quad{ }^{* *} p<0.01$, ns; non significant Lipid peroxidation is expressed as nmolof MDA formed per mg protein; Conjugated diene: $\mathrm{mM} / 100 \mathrm{gm}$ tissue; Hydro peroxide: $\mathrm{mM} / \mathrm{mg}$ tissue

There was heamorrhage and many side rophages present in carbofuran treated spleen. Section of spleen showed lymphoid folliclesmost of them showed prominent germinal centres, and many areas showed sinusoidal congestion, lymphstasis and histiocytic proliferation. There was no sinusoidal congestion in spleen after green tea treatment (Figure 1).

\section{Discussion}

Acetylcholinesterase (AChE) which catalyzes the hydrolysis of neurotransmitter acetylcholine (Ach) is one of the most essential enzymes in the family of serine hydrolases that a key role in memory and cognition (Xu Y et al., 2008). When AChE activity decreases, $\mathrm{ACh}$ is not broken and it accumulates within the synapses and cannot function in a normal way (Dutta and Arends, 2003). The present study demonstrated that there was a restoration in the decreased AChE activity produced by carbofuran in serum and tissues in animals treated with green tea extracts.

Lactate dehydrogenase (LDH) is a cytoplasmic enzyme present in essentially all major organ systems. The extracellular appearance of LDH is used to identify cell damage or cell death (Lott and Nemensanszky, 1969). It is released into the peripheral blood after cell death by, e.g., ischaemia, excess heat or cold, starvation, dehydration, injury, exposure to bacterial toxins, after ingestion of certain drugs, and from chemical poisonings (Glick, 1969). LDH is elevated during organophosphates or carbamate poisoning (Ranjan et al., 2010). The increase in plasma LDH activity reflects damage to a range of tissues including skeletal or cardiac muscles, kidney and liver. 


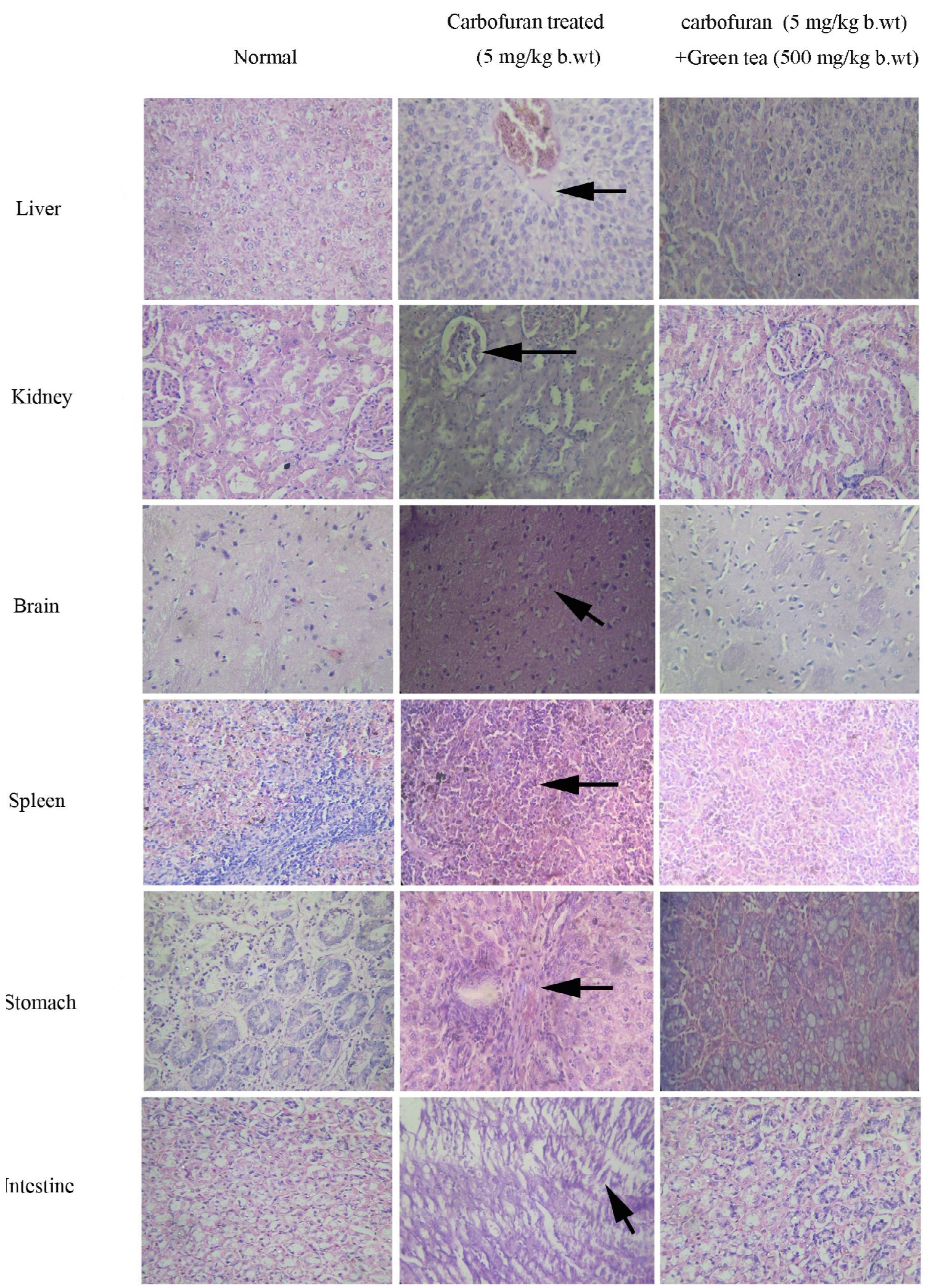

Figure 1: Effect of green tea on carbofuran induced histopathological changes in wistar rats arrows indicates histopathological changes associated with carbofuran treatment. 
The serum level of muscle enzyme such as creatine kinase is a marker of the functional status of muscle tissue and varies widely in both pathological and physiological conditions. An increase in these enzymes may represent an index of cellular necrosis and tissue damage, following acute and chronic muscle injuries (Mokuno et al., 1987). Serum CK was first used as a diagnostic aid in progressive muscular dystrophy (Ebashi et al., 1959) and considered as the main enzyme for the determination of neuromuscular diseases. In our investigation, the increase in $\mathrm{CK}$ and LDH activity were dose-dependent. GGT is involved in the transfer of amino acid across the cell membrane. Further, GGT had a role in glutathione metabolism, transferring the glutamyl moiety to various acceptor molecules, including L-amino acids and peptides. Such a process results in the retention of the cysteinyl glycine, which was considered to have a role in the preservation of intracellular homeostasis during oxidative stress. In our investigation, increased activities of these enzymes in serum and tissues could be due to the release of the enzyme from damaged tissues into circulation by the toxic effect of carbofuran. Administration of green tea $(500,250$ and $100 \mathrm{mg} / \mathrm{kg})$ for a period of 30 days, significantly prevented the carbofuran induced elevation in the activities of these diagnostic marker enzymes in serum, and tissues.

Decrease in the activities of liver mitochondrial enzymes such as ICDH, SDH, MDH and NADH dehydrogenase and alterations in carbohydrate metabolizing enzymes like hexokinase, glucose 6 phosphate dehydrogenase, glucose 6 phosphatase as well as fructose 1,6 bis phosphatase were also observed by the administration of carbofuran to rats and green tea treatment restored these enzymes, levels.

Antioxidant is a substance that when present at low concentrations compared to that of an oxidizable substrate, significantly delays or prevents oxidation of substrate (Halliwell and Gutteridge, 1999). Antioxidant enzymes comprise the antioxidant defence system of the body against oxidative stress evoked by various xenobiotics (Ahmad and Mukhtar, 1999). The present results showed that green tea, by virtue of its antioxidant properties significantly enhanced antioxidant defense mechanism. This was supported by a marked increase in catalase, SOD, GPX and GSH activities in the liver and lowering of LPO, conjugated dienes and tissue hydro peroxides in green tea treated liver exposed to carbofuran.

\section{Conclusion}

Pesticide Carbofuran has been shown to produce severe neurotoxicity in mammals by inhibiting the activity of acetylcholineesterase. Green tea extract administration significantly reduced the neurotoxicity as seen from the increased levels of acetylcholinesterase levels in serum and tissue. Green tea extract also reduced the tissue toxicity as seen from the decreased levels of creatine kinase, lactate dehydrogenase, $\alpha$-glutamyl transferase which were increased by the administration of carbofuran. Administration of green tea extract normalized the mitochondrial and carbohydrate metabolizing enzymes which were decreased by carbofuran on administration. Carbofuran induced oxidative stress in rats was also reduced by theadministration of green tea extract. Moreover, reduced levels of antioxidant enzymes in the tissues and serum produced by carbofuran were significantly elevated by administration of green tea extract. The biochemical alterations accompanied by histopathological changes resulted from carbofuran exposures were alleviated following green tea administration. These results indicate the ameliorating effect of green tea extract during carbofuran induced toxicity.

\section{Acknowledgements}

The authors are thankful to the Managing Director, Amala Cancer Research Centre, Amala Nagar, Thrissur for providing necessary facilities.

\section{Conflict of interest}

All the authors declare that there are no conflicts of interest in the course of conducting the research. Both the authors had final decision regarding the manuscript and decision to submit the findings for publication.

\section{References}

Aebi, H. (1974). Catalase estimation in Methods of Enzymatic Analysis, edited by Academic Press, New York, pp:673.

Ahmad, N. and Mukhtar, H. (1999). Green tea polyphenols and cancer: biologic mechanisms and practical implications. Nutr. Rev., 57: $78-83$

Balentine, D.A.; Wiseman, S.A. and Bouwens, L.C. (1997). The chemistry of tea flavonoids. Crit. Rev. Food Sci. Nutr., 37:693-704.

Binitha, P.P.; Sindhu, E.R and Kuttan, R. (2015). Mechanism of toxicity of carbofuran in wistar rats. J. Toxicol. Health, 106:503-16.

Brandstrup, N.; Kirk, J.E. and Bruni, C. (1957). Determination of hexokinase and phosphoglucoisomerase activities of arotic and pulmonary artery tissue in individuals of various ages. J. Gerentol., 12:16671.

Bun, S.S.; Bun.H.; Gue'don D.; Rosier C. and Ollivier, E. (2006). Effect of green tea extracts on liver functions in wistar rats. Food Chem. Toxicol., 44:1108-1113.

Chandra, A.K.; Choundry, S.R. and De.N. (2011). Effect of green tea (Camellia sineness L.) on morphological and functional changes in adult male gonads of albino rats. Indian J. Exp. Biol., 49:689-697.

Dutta, H.M. and Arends, D.A. (2003). Effects of endosulfan on brain acetylcholinesterase activity in juvenile bluegill sunfish. Environ. Res., 91:157-162.

Ebashi, S.; Toyokura, T.; Momoi, T. and Sugita, H. (1959). High creatine phosphokinase activity of sera of progressive muscular dystrophy patients, Biochem. J., 46:103-106.

Eels, H.A. and Kirkman, H.N.A (1961). Colorimetric method for assay of erythrocytic glucose-6-phosphate dehydrogenase. P. Soc. Exp. Biol. Med., 106:607-609.

Fantania, H.; Al-Nassar, E.K. and Sidhan, V. (1993). Purification and partial characterization NADP+ -linked isocitrate dehydrogenase from rat of liver cytosol. FEBS Lett., 320:57-60.

Farahani, G.H.N.; Zakaria, Z.;Kuntum, A.; Omar, D. and Sahid, I. (2007). Adsorption and desorption of carbofuran in Malaysia soils. Adv Environ. Biol., pp:20-26.

Fiske, H.C. and Subbarow, Y. (1925). The colorimetric determination of phosphorus. J. Biol. Chem., 66:375-400.

Fukuto, T.R. (1990). Mechanism of action of organophosphorus and carbamate pesticides. Environ. Health Persp., 87:245-54.

Gancedo, J.M. and Gancedo, C. (1971). Fructose-1, 6-disphosphatase, phosphofructokinase and glucose-6-phosphate dehydrogenase from fermenting and non-fermenting yeasts. Arch. Microbiol., 76:132. 
Glick, J.H. (1969). Serum lactate dehydrogenase isoenzyme and total lactate dehydrogenase values in health and disease, and clinical evaluation of these test by means of discriminant analysis. Am. J. Clin. Pathol., 52:320-328.

Hafeman, D.G.; Sundae, R.A. and Houestra, W.G. (1974). Effect of dietary selenium on erythrocyte and liver glutathione peroxidase in the rat. J. Nutr., 104:580.

Halliwell, B. and Gutteridge, J.M.C. (1999). Free radicals in Biology and Medicine, 3rd ed. Edited by Oxford University Press., Oxford, pp:112-118.

Hsu, T.C.; Zhao, Y. and Wang, R. (2001). Comparative efficacy as antioxidants between ascorbic acid and epigallocatechingallate on cells of two human lymphoblastoidline. Cancer Genet. Cytogen.,124:169-171.

John, A.B. and Steven, D.A. (1978). Microsomal lipid peroxidation in methods in enzymology, edited by academic Press, New York, pp:302.

King, J. (1965). The phosphohydrolysases-acid and alkaline transaminase. In: Practical Clinical Enzymology, edited by Van Nosttrand Co. Ltd, London, pp:191-208.

Lott, J.A. and Nemensanszky, E. (1969). Lactate dehydrogenase. In: Lott JA, Wolf PL, eds. Clinical Enzymology, a Caseoriented Approach, pp:213-244.

Lowry, O.H.; Rosenbrough, N.J. and Farr, A.L. (1951). Protein measurement with the folinphenol reagent. J. Biol. Chem., 193:265-275.

Mandel, S.; Weinreb, O. and Reznichenk, L. (2006). Green tea catechins as brain- permeable, non toxic iron chelators to 'iron out iron' from the brai. J. Neural. Transm. Supp., 71:249-257.

Mc, Cord. J.M. and Fridovich, J. (1969). Super oxide dismutase enzyme function for erythrocaprein. J. Biochem., 224:6049-6056.

Mehler, A.H.; Kornberg, A. and Grisolia, S. (1948). The enzymatic mechanism of oxidation and reduction between malate or isocitrate and pyruvate. J. Biol. Chem., 174:961-971.

Minakami, S.; Ringler, R.L. and Singer, T.P. (1962). Studies on the respiratory chain-linked dihydrodiphosphopyridine nucleotide dehydrogenase. I. Assay of the enzyme in particulate and in soluble preparations. J. Biol. Chem., 237:569-576.

Mokuno, K.; Riku, S.; Sugimura, K.; Takahashi, A.; Kato, K. and Osugi, O. (1987) Serum creatine kinase isoenzymes in Duchenne muscular dystrophy determined by sensitive enzyme immunoassay methods. Muscle Nerve, 10:459-463.
Moron, M.A.; Depierre, J.W. and Mannervick, B. (1979). Levels of glutathione, glutathione reductase and glutathione-S-transferase activities in rat liver. Biochim. Biophys. Acta., 82:67-68.

Nulton-Persson, A.C. and Szweda, L.I. (2001). Modulation of mitochondrial function by hydrogen peroxide. J. Biol. Chem., 276:23357-23361.

Ohkawa, H.; Oshishi, N. and Yagi, K. (1979). Assay for lipid peroxide in animal tissue by thiobarbituric acid reaction. Anal. Biochem., 95: $351-358$.

Paschka, A.G; Butler, C.Y.F. and Young (1998). Induction of apoptosis in prostate cancer cell lines by the green tea component, (-) epigallocatechin-3-gallate. Cancer Lett., 130:1-7.

Polu, P; Narayanabhirama, U and Khan, $\mathbf{S}$ (2015). Herbal medicinal plants as an anticancer agents. Ann. Phytomed., 4:37-45.

Ranjan, R.; Uppal, S.K.; Chand, N.; Dhaliwal, P.S. and Dumka, V.K. (2010). Clinicohaemato biochemical profile in organophosphate/carbamate compound poisoned bovine. Indian Veter. J., 87:178-179.

Salman, J.M.; Abid, F.M. and Muhammed, A.A. (2011). Adsorption of carbofuran insecticide from aqueous solution using commercial activated carbon. Int. J. Chem. Sci., 9:557-564.

Srinivasan, P.; Sabitha, K.E. and Shyamaladevi, C.S. (2007). Attenuation of 4Nitroquinoline 1-oxide induced in vitro lipid peroxidation by green tea polyphenols. Life Sci., 12:1080-1086.

Srinivasan, P.; Sabitha, K.E. and Shyamaladevi, C.S. (2006). Modulatory efficacy of green tea polyphenols on glycoconjugates and immunological markers in 4-Nitroquinoline 1-oxide-induced oral carcinogenesis-A therapeutic approach. Chem. Biol. Interact., 162:149-156.

Susin, S.A.; Larochette, N. and Geuskens, M. (2000). Purification of mitochondria for apoptosis assays. Methods Enzymol., 322:205208.

Tottor, D. (1991). Aquatic fate and effects of carbofuran. Crit. Rev. Environ. Contr., 21:137-176.

Vogel, G.H. (2002). Drug discovery and evalution: Pharmacological assays. Springer - Verlag Berlin Heidel berg.

Xu, Y.; Colletier, J.P and Jiang, H. (2008). Induced-fit or preexisting equilibrium dynamics? Lessons from protein crystallography and MD simulations on acetylcholinesterase and implications for structure-based drug design. Protein Sci., 17:601-605.

Zhang, Q.; Kelly, A.P and Wang, L. (2006). Green tea extract and (-)epigallocatechin-3-gallate inhibit mast cell-stimulated type I collagen expression in fibroblasts. J. Investig. Dermatol., 126: 2607-2613. 